\title{
Prevalence and effect of spawner-isolated mortality virus on the hatchery phases of Penaeus monodon and $P$. merguiensis in Australia
}

\author{
Leigh Owens ${ }^{1, *}$, Catriona McElnea ${ }^{1}$, Natale Snape ${ }^{1}$, Lachlan Harris ${ }^{2}$, Malcolm Smith ${ }^{2}$ \\ ${ }^{1}$ Discipline of Microbiology and Immunology, James Cook University, Townsville 4811, Australia \\ ${ }^{2}$ Seafarm Ltd, Ella Bay Road, Flying Fish Point, Innisfail 4860, Australia
}

\begin{abstract}
Spawner-isolated mortality virus (SMV) has been associated with mortalities in broodstock of Penaeus monodon and with mid-crop mortality syndrome on grow-out farms. Epidemiological evidence suggested an association between the SMV status of broodstock and subsequent survival of their progeny, and this paper describes investigations into that association. The faeces of 909 broodstock in 9 different groups were tested by a polymerase chain reaction (PCR) for SMV and positive results were confirmed by an internal dot-blot. Seventy-seven spawners $(8.5 \%)$ were positive for SMV with prevalence ranging from 0 to $24 \%$ among groups. The prevalence in spawners of P. monodon was higher $(24 \%)$ than in P. merguiensis $(4 \%)$. Three longitudinal studies were undertaken to compare the survival of progeny from broodstock that were positive to SMV with those that were not. Survival in hatchery tanks of progeny from SMV-positive spawners was lower than those from SMV-negative spawners with reductions of $23 \%(p=0.01), 7.3 \%(p=0.214)$ and $18.9 \%(p=$ 0.129 ) in the 3 studies. The conclusions were less consistent when examined during each of the later stages of growth in hatchery pools, nursery and grow-out ponds, with progeny from SMV-postive spawners sometimes having better survival rates. However, survival was better overall in progeny from SMV-negative spawners. Simple linear regression showed survival was negatively related to the proportion of postlarvae from SMV-positive spawners, with a decrease in survival of $5.6 \%$ for each $10 \%$ increase in the proportion of postlarvae coming from SMV-positive spawners $(p=0.006)$. Data from 38 ponds showed $6.71 \%$ of losses were due to SMV. If these losses were consistent across the entire industry, the annual loss due to SMV would have been approximately AUD 3 million in $1999 / 2000$.
\end{abstract}

KEY WORDS: Spawner-isolated mortality virus - Penaeus monodon - Production - Economics · Polymerase chain reaction

\section{INTRODUCTION}

Spawner-isolated mortality virus (SMV) was first identified as causing epizootic mortalities in Penaeus monodon spawners held in a research breeding facility (Fraser \& Owens 1996). When the first outbreaks of mid-crop mortality syndrome (MCMS) occurred in Australian prawn farms in 1994, SMV was identified as being involved (Owens 1997). Later, other pathogens such as lymphoid organ virus and gill associated virus were believed to contribute to mortalities in MCMS. In northern Queensland, 3 of 4 initially affected farms received postlarvae from a single hatchery in the month of January 1994. Survival plummeted in these ponds and this prefaced the on-going mortality problems of MCMS. This observation reinforced an earlier hypothesis that SMV was vertically transmitted through hatcheries (Fraser \& Owens 1996). Furthermore, data from the field continued to point to infection and mortalities occurring very early during the growout period $(<4 \mathrm{wk}$ after stocking) or even in the first week (Young 1997, Snape 1998), again implicating 
hatcheries as a source of infection. Therefore, it was important to further investigate this suspected hatchery link in order to produce better control strategies.

In situ hybridisation of Penaeus monodon using a gene probe developed for SMV had shown that the major trophic tissue, and usually the first tissue infected, was the gastrointestinal tract (Owens et al. 1998). Target organs included the hepatopancreas, midgut caecae, midgut and to a lesser extent, the hindgut caecae. In a heavy infection, the virus would break through the lamina propria of the gut and become systemic, localising in the lymphoid organ, gonads and heart. Therefore, the most likely route of egress of SMV would be through the gut, voided with the faeces. Since the faeces can be tested without sacrificing the broodstock and it appeared likely that SMV was shed in the faeces, a polymerase chain reaction (PCR) test was developed to detect SMV in faecal casts.

This paper describes the production of the SMV-PCR for testing spawner faeces, the results obtained using such a PCR in commercial hatcheries and farms, and the implications for prawn production.

\section{MATERIALS AND METHODS}

Design. The SMV status of 909 individually housed broodstock located at 3 commercial hatcheries between December 1997 and September 1999 was determined by faecal PCR. These broodstock represented 9 groups tested at different times during the study. The prevalence of SMV infection in broodstock was estimated and compared among groups.

The survival rates were then estimated and compared for 231 batches of postlarvae from some of these spawners in 3 longitudinal studies. In the first study, the survival of 42 mixed batches of Penaeus monodon postlarvae from multiple spawners was estimated in the hatchery tanks and again in the grow-out ponds. In the second study, 124 batches of $P$. monodon postlarvae in hatchery tanks were monitored and transferred to hatchery pools, where 108 of those batches continued to be monitored, and then 49 of these batches were transferred to nursery ponds and monitored there. In the third study, 65 batches of $P$. merguiensis postlarvae in hatchery tanks were monitored, followed to hatchery pools, where 61 of these batches were monitored and then 48 of these batches were monitored in nursery ponds.

The effect of the level of SMV contamination on survival of Penaeus mondon progeny was also assessed. As tank space was at a premium in the hatcheries, progeny of infected $P$. monodon spawners were mixed with the progeny of non-infected spawners to reach the optimum rearing density for 23 of the batches of progeny in Study 1. Contamination was estimated by the proportion of larvae coming from SMV-positive spawners divided by the total number of larvae in the tank. This led to different rates of SMV contamination of batches and the subsequent survival of progeny was monitored in both the hatchery and grow-out ponds.

To determine if there was a transfer of SMV from the hatcheries to grow-out ponds, in situ hybridisation was used each week to determine the SMV status of 20 individuals per pond for those 2 ponds with the lowest estimated survival through to harvest. This was then used to estimate the change in SMV prevalence during the first 6 wk in grow-out ponds.

Survival estimation. Survival was estimated on a weekly basis by counting the number of larvae in $5 \times 11$ aliquots and extrapolating to the final tank, pool or pond volume. Errors in estimates do occur, as seen by the higher than $100 \%$ survival in Fig. 1. However, hatcheries are paid by the number of postlarvae delivered to the grow-out farms and, therefore, their estimates are generally reliable.

Faecal collection. Faeces were collected from individually housed, female broodstock held overnight in the broodstock tanks as soon as possible after they arrived in the hatchery. Faecal samples were boiled immediately after collection in TE buffer $(20 \mathrm{mM}$ TrisHCL, 10 mM EDTA, pH 8.0; Sambrook et al. 1989) as laboratory studies had shown that proteases and nucleases present in the faeces quickly destroyed any virus present. The samples were then stored at $-20^{\circ} \mathrm{C}$ until further processing.

DNA extraction from faeces. The method used to extract DNA reduces melanin from the extract which inhibits PCR (Giambernardi et al. 1998). Samples were vortexed to disrupt the faecal strings and digested with $200 \mathrm{\mu g} \mathrm{ml}^{-1}$ Proteinase K (PK) and triton X-100 for $2 \mathrm{~h}$ at $56^{\circ} \mathrm{C}$. The DNA was then selectively attached to silica and proteins denatured with a chaotropic agent ( $\mathrm{NaI}_{i}$ Progen Industries, Bandpure ${ }^{\mathrm{TM}}$ ). The nucleic acid extract was washed and eluted in accordance with the manufacturer's instructions. The DNA was resuspended in a final volume ratio of 30:1 of $10 \mathrm{mM}$ Tris$\mathrm{HCl} \mathrm{pH} \mathrm{8.0.} \mathrm{Five} \mathrm{microlitres} \mathrm{of} \mathrm{the} \mathrm{extract} \mathrm{was} \mathrm{used} \mathrm{in}$ a 25:1 ratio PCR.

Testing of spawners. A combination of 2 sets of PCR primers (SMV260, SMV200) and a DIG-labelled dot blot confirmation test (SMV150) for the smaller amplicon was designed from a cloned piece of SMV DNA. As the SMV200 had a confirmation step with the internal dot blot (SMV150), this test was accepted as the 'gold standard' detection test. Assigning SMV200 with the dot blot confirmation test as the gold standard (100\% sensitivity and specificity), SMV260 had a relative sensitivity of $3.2 \%$ and relative specificity of $97 \%$. 
SMV200 alone had an improved relative sensitivity of $93.6 \%$ and relative specificity of $100 \%$. For the first set of faecal samples (December 1997), those samples producing amplicons with either set of primers were scored as positive. Thereafter, samples scored as positive were those that were positive on confirmation with the dot blot. This test detected about 100 copies of the genome of SMV.

Labelling of SMV gene probe. The SMV gene probe was labelled with DIG-11-dUTP (Boehringer Mannheim) using the PCR and M13 primers, whose complementary sequences were incorporated into the vector which contained cloned SMV DNA. The reaction cocktail included $150 \mu \mathrm{M}$ dNTP $(30 \mu \mathrm{M}$ DIG-11-dUTP and $120 \mu \mathrm{M}$ dTTP), $0.5 \mu \mathrm{M}$ primers, $2.5 \mathrm{mM} \mathrm{MgCl}_{2}$ and $1 \mathrm{U}$ of $T$ th polymerase (Biotech International) in a reaction volume of $50 \mu \mathrm{l}$. The reaction mixture was initially heated to $95^{\circ} \mathrm{C}$ for $4 \mathrm{~min}$, then denatured at $95^{\circ} \mathrm{C}$, annealed at $55^{\circ} \mathrm{C}$, both for $50 \mathrm{~s}$, and extended at $72^{\circ} \mathrm{C}$ for $2 \mathrm{~min}$; this was repeated 35 times with a final extension time of $7 \mathrm{~min}$. An aliquot was electrophoresed through $1 \%$ agarose to determine purity of the PCR product. Unincorporated DIG-dUTP was separated from labeled product using ultrafiltration by centricon 100 (Amicon) and the concentration of probe estimated by comparison with a labelled standard (Boehringer Mannheim) following the protocol provided by the manufacturer.

Processing of specimens. Prawns were caught with a $1 \mathrm{~m}$ beam trawl in grow-out ponds. They were fixed in Davidson's fixative by injection and immersion for $24 \mathrm{~h}$, after which specimens were transferred to $70 \%$ ethanol for subsequent storage (Bell \& Lightner 1988). Following fixation, specimens were processed and embedded as described by Culling et al. (1985). Sections of $5 \mu \mathrm{m}$ were cut and adhered to silane (Sigma)treated glass slides and left overnight at $60^{\circ} \mathrm{C}$.

Hybridisation. The in situ hybridisation method used was based on that described by Rolighed \& Lindeberg (1996) with some modifications. Briefly, tissue sections were deparaffinised through xylene, washed several times in ethanol and rehydrated in distilled water, and finally equilibrated in TNE $(50 \mathrm{mM}$ Tris$\mathrm{HCl} \mathrm{pH} \mathrm{7.4,} 10 \mathrm{mM} \mathrm{NaCl}, 1 \mathrm{mM}$ EDTA) buffer. Tissues were then made permeable to probe by digestion with PK $100 \mu \mathrm{g} \mathrm{ml}^{-1}$ at 37 to $56^{\circ} \mathrm{C}$ for $10 \mathrm{~min}$. Digestion was stopped by addition of glycine to a final concentration of $0.2 \%(\mathrm{w} / \mathrm{v})$. Tissues were then stablised in $0.4 \%$ paraformaldehyde for $5 \mathrm{~min}$ at $4^{\circ} \mathrm{C}$. This was followed by 2 washes in double distilled water for 5 min after which tissues were air dried for $5 \mathrm{~min}$. The probe was then applied at a concentration of $1 \mathrm{ng} \mathrm{\mu l}^{-1}$ in hybridisation buffer $(50 \%$ formamide, $5 \%$ dextran sulphate, $0.5 \mathrm{mg}$ sperm DNA ml${ }^{-1}$, Denhardt's solution, $4 \times \mathrm{SSC}$ [0.15 M NaCl, $0.015 \mathrm{M}$ sodium citrate, $\mathrm{pH} 7.0]$ ), a cov- erslip applied, then tissue and probe DNA denatured simultaneously at $95^{\circ} \mathrm{C}$ for $8 \mathrm{~min}$. Slides were immediately quenched on ice for $1 \mathrm{~min}$ and hybridised at $37^{\circ} \mathrm{C}$ overnight. Nonspecifically bound probe was removed by washing in $2 \times \mathrm{SSC}$ twice for $5 \mathrm{~min}$ at room temperature and once in $0.1 \times \mathrm{SSC}$ at $37^{\circ} \mathrm{C}$. Detection of bound probe was carried out in accordance with the protocol described by Durand et al. (1996) with colour development carried out overnight. Tissues were counterstained with $0.5 \%$ aqueous Bismarck Brown for $30 \mathrm{~s}$ and mounted with Crestia (Scientific Supplies) and Depex (Gurr).

Statistical analyses. Confidence limits for prevalence were calculated using exact binomial methods while infection and survival rates were compared using Pearson Chi-squared tests (EpiInfo 6.04d, Centers for Disease Control and Prevention 2001). Simple linear regression (Statistix 7.0, Analytical Software 2000) was used to test the association between the proportion of postlarvae from SMV-positive spawners and subsequent survival of Penaeus monodon.

\section{RESULTS}

\section{Faecal testing}

Overall, 77 of the 909 spawners $(8.47 \%)$ tested positive for SMV (Table 1). However, there was significant variation in the prevalence among the 9 groups examined ( $\mathrm{p}<0.001$ ). Prevalence ranged from 0 to $24 \%$ but it was not possible to evaluate trends over time as there was insufficient data. Not all the broodstock from which faecal samples were taken were identified to species. In those that were identified, the prevalence was $24 \%$ in Penaeus monodon and $4 \%$ in P. merguiensis (Table 1 ) and the difference was significant $(\mathrm{p}<0.001)$.

\section{Larval survival}

Survival estimates were obtained for all 3 longitudinal studies for (1) hatchery tanks, (2) hatchery pools and nursery ponds in Studies 2 and 3, and (3) grow-out ponds in Study 1 (Table 2). Survival of postlarvae in hatchery tanks was lower for SMV-infected broodstock in all studies $(-23,-7.3,-18.9 \%)$ but only significant in Study $1(-23 \%, p=0.01)$. In hatchery pools, it was significantly lower in Study $2(-14.9 \%, p=0.008)$ and higher in Study 3 though this was not significant $(13 \%$, $\mathrm{p}=0.327$ ). In nursery ponds, it was significantly lower in Study $3(-23.7 \%, p=0.016)$, and higher in Study 2, though this was not significant $(6.03 \%, p=0.305)$. In the grow-out ponds it was lower in Study 1 but this was not significant $(-15 \%, \mathrm{p}=0.339)$. 
Table 1. Prevalence of spawner-isolated mortality virus (SMV)-infected spawners at hatcheries detected by PCR/dot blot on faecal samples. Not all broodstock were identified to species and this explains the discrepancy in the total number of broodstock when compared with the sum of the numbers of Penaeus monodon and P. merguiensis

\begin{tabular}{|lccc|}
\hline Date & $\begin{array}{c}\text { No. positive/ } \\
\text { no. of broodstock }\end{array}$ & $\begin{array}{c}\text { Prevalence } \\
(\%)\end{array}$ & $\begin{array}{c}95 \% \text { confidence } \\
\text { limits }\end{array}$ \\
\hline Dec 1997 & $7 / 30$ & 23 & $9.8-42$ \\
Jan 1998 & $1 / 102$ & 1 & $1-4.6$ \\
Feb 1998 & $7 / 70$ & 10 & $3.5-15$ \\
Mar 1998 & $10 / 126$ & 8 & $3.8-11.5$ \\
Aug 1998 & $6 / 138$ & 4 & $1-9$ \\
Sep 1998 & $8 / 108$ & 7 & $3-13.8$ \\
Dec 1998 & $7 / 176$ & 4 & $1.6-8$ \\
Sep 1999 & $31 / 131$ & 24 & $16.8-32.5$ \\
Sep 1999 & $0 / 28$ & 0 & $0-11.6$ \\
Total & $77 / 909$ & 8.47 & $6.3-10.3$ \\
P. monodon & $65 / 266$ & 24.4 & $19.4-30.4$ \\
P. merguiensis & $12 / 277$ & 4.33 & $2.3-7.8$ \\
\hline
\end{tabular}

Linear regression showed that survival was negatively related to the proportion of postlarvae from SMV-infected spawners (Fig. 1). The estimated survival rate for uncontaminated progeny was approximately $74 \%(p=0.000)$ while survival rate decreased by $5.6 \%$ for each $10 \%$ increase in the proportion of postlarvae coming from SMV-positive spawners $(\mathrm{p}=0.006)$.

Most of the deaths of postlarvae occurred at PL 10-12 (90\%) with a range of PL 9-16. Study 3 consisted of Penaeus merguiensis. Because their growth rates were higher, they were moved through the hatchery more quickly than were comparable batches of $P$. monodon, and differences in mortalities were greater at a later stage of the production cycle for this species.

The lack of statistical significance in some instances may have been due to lack of statistical power because of relatively small sample sizes. For example, the difference in survival in hatchery tanks in Study 3, shown in Table 2, is large $(18.9 \%)$ but not statistically significant.

\section{Prevalence of SMV in grow-out ponds}

In situ hybridisation indicated that Pond 1 had approximately a $20 \%$ prevalence of SMV for the first $3 \mathrm{wk}$ that then dropped to $0 \%$ for the rest of the sampling period (Fig. 2). Pond 2 had an initial prevalence of SMV of $35 \%$ at 3 d post-stocking, which became undetectable for $3 \mathrm{wk}$ and then rose to $60 \%$ by Week 6 (Fig. 2). Due to the low number of prawns sampled each week (20), the prevalence estimates are insufficiently precise to draw any firm conclusions. For example, a prevalence estimate of $0 \%$ has an upper $95 \%$ confidence limit of $17 \%$ for a sample size of 20 .

\section{DISCUSSION}

Previous observations suggested that SMV was vertically transmitted through hatcheries. We have been able to provide further evidence of a hatchery link and quantify its impact to some extent. SMV was first identified as causing epizootic mortalities in Penaeus monodon spawners held in a research breeding facility (Fraser \& Owens 1996). When the first outbreaks of MCMS occurred in Australian prawn farms in 1994,

Table 2. Survival of progeny of spawner-isolated mortality virus (SMV)-PCR positive spawners compared to SMV-PCR negative spawners at different stages of the production cycle for Penaeus monodon and P. merguiensis. Study 1 consisted of mixed batches from multiple spawners. If 1 spawner of a batch was positive, that batch was classified positive. In Studies 2 and 3 each batch was from an individual spawner. ns: non-significant

\begin{tabular}{|c|c|c|c|}
\hline & $\begin{array}{c}\text { Study } 1 \\
P . \text { monodon } \\
\text { survival \% }\end{array}$ & $\begin{array}{c}\text { Study } 2 \\
\text { P. monodon } \\
\text { survival \% }\end{array}$ & $\begin{array}{c}\text { Study } 3 \\
\text { P. merguiensis } \\
\text { survival \% }\end{array}$ \\
\hline Hatchery tanks & 42 batches & 124 batches & 65 batches \\
\hline SMV-negative spawners & 74 & 60.8 & 59.6 \\
\hline SMV-positive spawners & 51 & 53.5 & 40.7 \\
\hline Difference & -23 & -7.3 & -18.9 \\
\hline Significance & $\mathrm{p}=0.01$ & $\mathrm{~ns}, \mathrm{p}=0.214$ & $\mathrm{~ns}, \mathrm{p}=0.129$ \\
\hline Hatchery pools & & 108 batches & 61 batches \\
\hline SMV-negative spawners & & 61.2 & 76 \\
\hline SMV-positive spawners & & 46.3 & 89 \\
\hline Difference & & -14.9 & 13 \\
\hline Significance & & $\mathrm{p}=0.0077$ & $\mathrm{~ns}, \mathrm{p}=0.327$ \\
\hline Nursery ponds & & 49 batches & 48 batches \\
\hline SMV-negative spawners & & 49.3 & 72 \\
\hline SMV-positive spawners & & 55.6 & 49.3 \\
\hline Difference & & 6.03 & -23.7 \\
\hline Significance & & $\mathrm{ns}, \mathrm{p}=0.305$ & $p=0.016$ \\
\hline Grow-out ponds & 38 batches & & \\
\hline SMV-negative spawners & 66.5 & & \\
\hline SMV-positive spawners & 51.5 & & \\
\hline Difference & -15 & & \\
\hline Significance & $\mathrm{ns}, \mathrm{p}=0.339$ & & \\
\hline
\end{tabular}




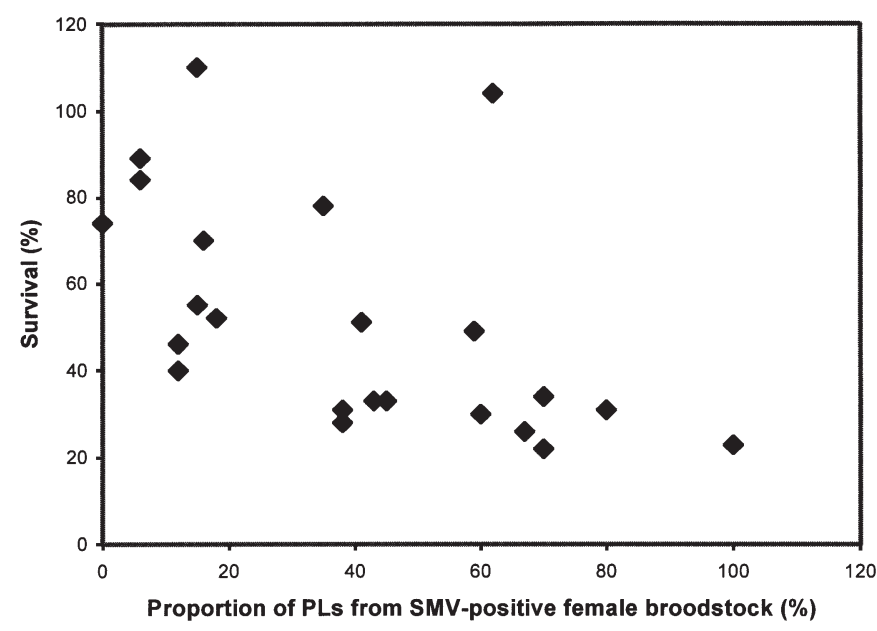

Fig. 1. Relationship between the survival of postlarvae of Penaeus monodon and the rate of contamination with spawner-isolated mortality virus (SMV). Survival of greater than $100 \%$ is due to errors in the method of estimating the total number of larvae from counting subsamples and extrapolating to the whole batch. The fitted simple linear regression line is $y=72.69-0.529 x$. p-values for the intercept and slope were 0.000 and 0.006 respectively

SMV was identified as being associated with the mortalities (Owens 1997). In northern Queensland farms, 3 of 4 initially affected farms received postlarvae from a single hatchery in January 1994. Once SMV becomes systemic in prawns by breaking through the lamina propria of the gut into the haemocoel, one of the main tissues that become probe-positive are the gonads (Owens et al. 1998). This suggests a possible mechanism for vertical transmission from broodstock to postlarvae through infected reproductive tissues.

Furthermore, virus is released in the faeces of spawners and this can also contaminate eggs during spawning.

In hatchery tanks, postlarvae from SMV-positive spawners had poorer survival than those from SMV-negative spawners for all 3 data sets $(23,7.3$ and $18.9 \%$ worse). The picture was less consistent in the hatchery pools and nursery ponds, where data were collected in Studies 2 and 3 only. However, the compounded difference in survival from hatchery tanks to nursery ponds was $4.5 \%$ in Study $2(61.2 \times$ $49.3 \%-46.3 \times 55.6 \%)$ and $10.8 \%$ in Study $3(76 \times 72 \%-89 \times 49.3 \%)$, with postlarvae from SMV-positive spawners again performing the worse. Differences in grow-out ponds were only estimated in Study 1 where postlarvae from SMV-positive spawners had a $15 \%$ lower survival during this period. While variability between batches of prawns in hatcheries and ponds makes precise quantification of the impact of disease difficult, our best estimate from the present observations is that in northern Queensland SMV is probably causing reductions in survival of 15 to $35 \%$ over the entire production period. These estimates appear to be reasonable as data from Lobegeiger (1999) for the 1997-98 growout season indicate the average overall mortality rate to harvest, from stocking with postlarvae, is $65 \%$. Infection with lymphoid organ virus (Spann et al. 1995), the senior synonym of gill-associated virus (Spann et al. 1997), which is another viral component of MCMS, is also likely to contribute to these losses.

The finding of a significant negative linear relationship between survival and the proportion of postlarvae in a batch coming from SMV-positive spawners is further evidence both for vertical transmission and production loss from SMV which is related to the proportion of infected postlarvae.

Without further research, particularly in the growout stage, to establish the proportion of ponds infected with SMV, accurate figures for overall industry losses can not be reliably estimated. However, the current industry practice of mixing batches of postlarvae would ensure most had a high probability of being exposed to SMV. The data in this paper suggest that this practice led to $44.7 \%$ (17 out of 38 ) of ponds being contaminated. The market value at harvest of Australian Penaeus monodon was AUD 23.1 million in 1997-98 (Lobegeiger 1999), the period when MCMS was still a significant problem. Simplistically, if SMV caused a $15 \%$ survival reduction in the estimated

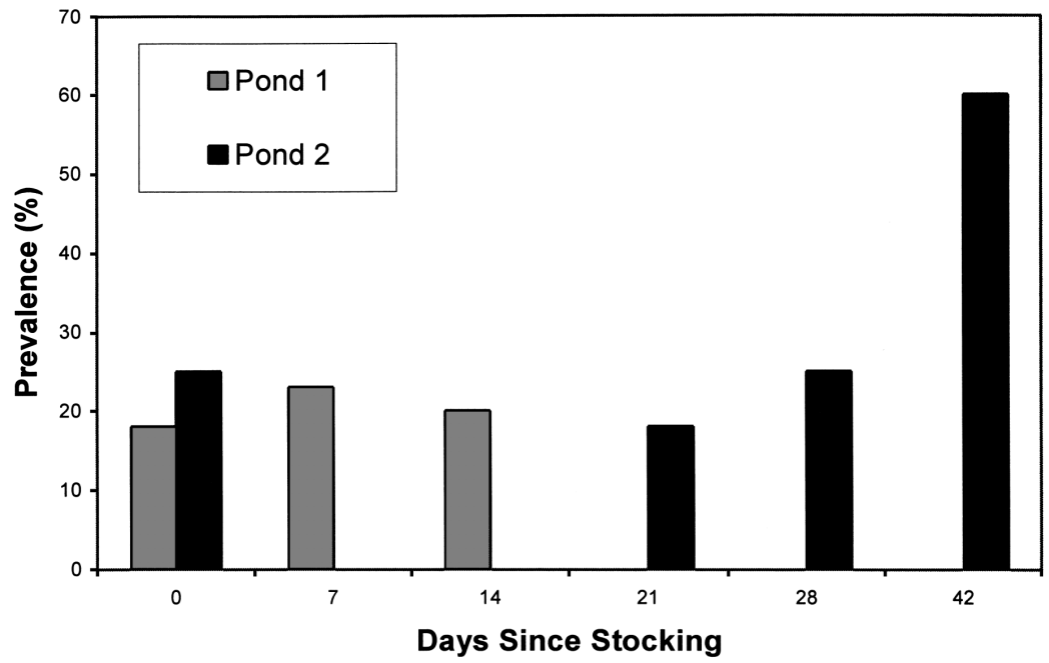

Fig. 2. Prevalence of SMV in 2 prawn ponds as detected using in situ hybridisation with a spawner-isolated mortality virus (SMV)-gene probe (Snape 1998) 
$44.7 \%$ infected ponds, then the minimum production lost to SMV was approximately AUD 1.7 million per year in grow-out, assuming that all prawn farming areas of Australia were affected. A further AUD 0.5 million was estimated to be lost in hatcheries (based on the figures in Lobegeiger 1999). This would have resulted in an annual loss of AUD 2.2 million to the $P$. monodon industry, which does not include wage costs nor opportunity costs in hatcheries. The laboratory costs for PCR-testing of all the spawners for the entire industry plus replacement costs of SMV-PCRpositive spawners are estimated at AUD 220000 to 250000, excluding costs of collecting and submitting spawner faeces from hatcheries. In 1999/2000, prawn production from aquaculture rose to AUD 35 million (Lobegeiger 2001) and, based on these figures, losses may be of the order of AUD 3 million. Although our findings suggest that a screening program for SMV in spawners is warranted, more detailed economic analyses would need to be undertaken to comprehensively compare all costs and benefits.

\section{CONCLUSIONS}

The findings from the present study support the hypothesis that SMV is vertically transmitted from spawners to postlarvae in hatcheries and causes reduced survival of progeny. Screening spawners for SMV using a PCR test on faeces may be a viable management option.

Acknowledgements. Many prawn farmers and hatchery operators have aided in the collection and analyses of the data. In particular, we would like to thank Seafarm, Australian Shrimp Holdings, Farmfresh, Searanch, Melivan, Janglade, Australian Institute of Marine Science, and Queensland Department of Primary Industries.

\section{LITERATURE CITED}

Bell TA, Lightner DV (1988) A handbook of normal penaeid

Editorial responsibility: Chris Baldock, South Brisbane, Queensland, Australia shrimp histology. World Aquaculture Society, Baton Rouge, FL Culling CFA, Allison RT, Barr WT (1985) Cellular pathology techniques, 4th edn. Butterworths, London

Durand S, Lightner DV, Nunan LM, Redman RM, Mari J, Bonami J (1996) Application of gene probes as diagnostic tools for white spot baculovirus (WSBV) of penaeid shrimp. Dis Aquat Org 27:59-66

Fraser CA, Owens L (1996) Spawner-isolated mortality virus from Australian Penaeus monodon. Dis Aquat Org 27:141-148

Giambernardi TA, Rodeck U, Klebe RJ (1998) Bovine serum albumin reverses inhibition of RT-PCR by melanin. Biotechniques 25(4):564-566

Lobegeiger R (1999) Report to farmers. Aquaculture Production Survey, Queensland 1997-98. Department of Primary Industries, Queensland

Lobegeiger R (2001) Report to farmers. Queensland Aquaculture Production Survey, 1999-2000. Department of Primary Industries, Queensland

Owens L (1997) Special topic review: the history of the emergence of viruses in Australian prawn aquaculture. World J Microbiol Biotechnol 13:427-431

Owens L, Haqshenas G, McElnea C, Coelen R (1998) Putative spawner-isolated mortality virus associated with mid-crop mortality syndrome in farmed Penaeus monodon from northern Australia. Dis Aquat Org 34:177-185

Rolighed J, Lindeberg H (1996) Detection of HPV 11 DNA in paraffin embedded laryngeal tissure with a DIG-labelled DNA probe. Non-radioctive in situ hybridization application manual, 2nd edn. Boehringer Mannheim, Mannheim, p 122-125

Sambrook J, Fritsch EF, Maniatis T (1989) Molecular cloning. A laboratory manual. Cold Spring Harbor Laboratory, Cold Spring Harbor, New York

Snape N (1998) A histopathological survey of cultured postlarval Penaeus monodon: invesigating midcrop mortality syndrome (MCMS) in a north Queensland farm. BSc (Hons) thesis, Department of Microbiology and Immunology, James Cook University

Spann KM, Vickers JE, Lester RJG (1995) Lymphoid organ virus of Penaeus monodon from Australia. Dis Aquat Org 23:127-134

Spann KM, Cowley JA, Walker PJ, Lester RJG (1997) A yellow-head-like virus from Penaeus monodon cultured in Australia. Dis Aquat Org 31:127-134

Young ND (1997) A histopathological survey investigating a new disease syndrome in the giant tiger prawn (Penaeus monodon) in north Queensland, Australia. BSc (Hons) thesis, Department of Microbiology and Immunology, James Cook University, Townsville

Submitted: December 20, 2000; Accepted: September 3, 2002 Proofs received from author(s): January 14, 2003 